乗用摘採機のはん用化に䦥する研究

臀林省荣業試験場 鈴 木 勝 弘

Studies on the Wide Application of the

Self-propelled Plucking Machine

By Katsuhiro SUZUKI

National Research Institute of Tea

1 緒言

震作業機は，本来專用機であるべきか，はん用機とす るのが望ましいかは䅤々諭議のあるところである。著者 は，さきに試作した乗用摘採機がかなりの馬力数㫗あり， 高洒でもあることから，摘堔のみならず，世九枝，中耕，

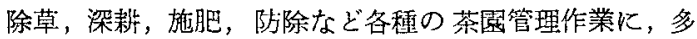
目的に利用することができれば，省力のみならず，生率
費の低滅をはかる上にす望ましいことであると考え，上 記の各種作業装置を設䛅，試作し，本機に装着して運程 訊験を奏施した。ここにその結果を報告する。

\section{2 せん枝装置に関する研究}

\section{1 整枝装置の試作}

竍作した整枝装置は，図 1 に示すように摘採機の刚刃 部を取り外し，3点ヒッキに連なる上・下リンクに直装

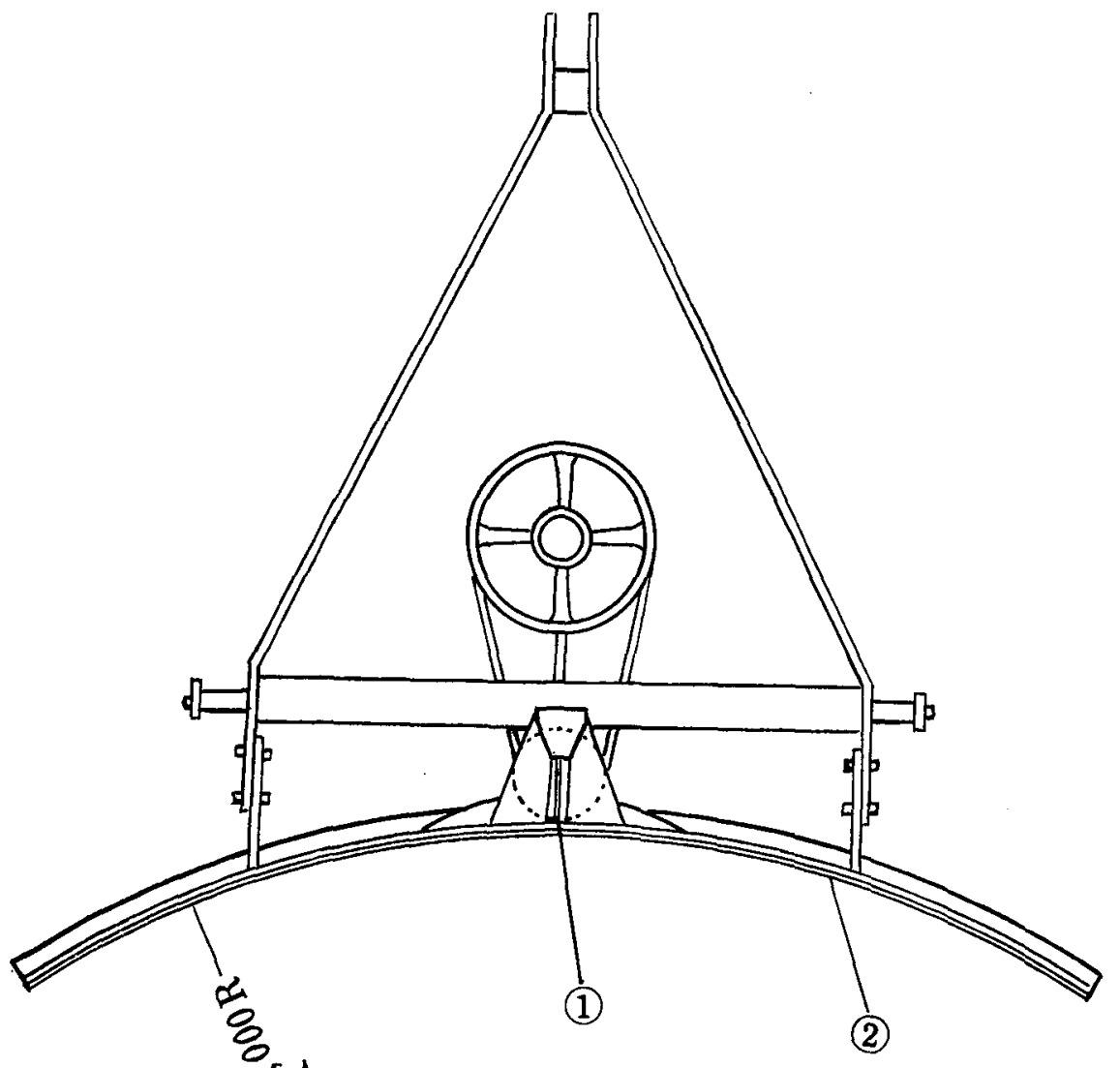

in

1. 払い羽根

2. 杊刃

3. P.T.O (4)

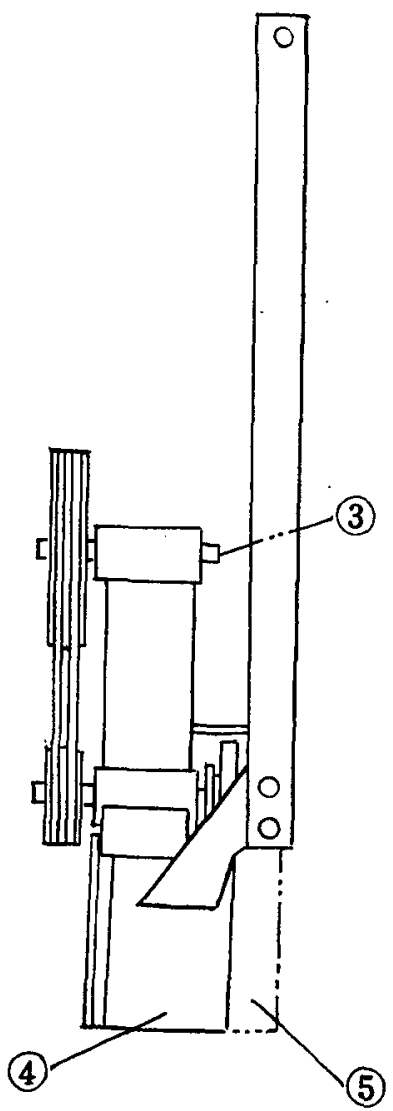

因1 女 九 枝淁置 
するものである。

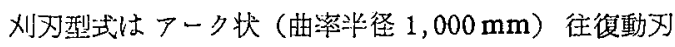
でピッチ $30 \mathrm{~mm}$ ，切断角 $25^{\circ}$ ，〈さび角 $35^{\circ}$ ，刐の厚さ

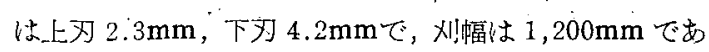
る。

刈刐の駆動は 自在接手招よび伸維軸により行ない，ク ランク部を刈刃の中心に取り付けた。この力法によれば， 当然切断された枝条がクランク部につか学ることが想定 されるため，これを払いのける羽根を左右に振らせた。

\section{2 試験結果および考察}

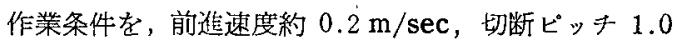
$\mathrm{cm}$ ，切断速庤比 5.9 (入川对往復数 1,200 c.p.m) て整枝 を夷施した。その結果は，一般的にいわれる整枝，つま り摘採面をとろえる作桬には何ら問題点はなく所期の目 的は達成された。

次にこの装置がどの程度をでのせん枝が可能であるか 試験した結果， $10 \mathrm{~cm}$ 程度ずつ何回かに分けて徐々に段

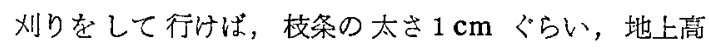
$30 \mathrm{~cm}$ 程度までのせん枝は可能であった。しかし， 一度に $10 \mathrm{~cm}$ 程度以上深くせん枝することは，払い羽根 が小さいこともあり，切断された枝条がクランク部，あ るいは刈刃の補強枠等につかえて連続作業ができなかっ た。その後，刚为と刚刃の支持枠との間隔を広げたり， 摘探機に装着されている送風機を利用して，刚刃の前方 にダクトを取り付け，切断された枝条を左右に吹き落す よ5改造したが，刈刃の歌動部が中央に位置することは， 切断された枝条が駆動部につかえて前進のさまたげとな り連続運転に支障をきたすことが諗められた。

\section{3. 世枝装置の試作}

前述のせん枝装置では，一度に深刚りすることが不可 能であることが認められたため，図2に示すような刚刃 の駆動をサイドドライブ方式とした茈置を試作した。 この装置は，地上 $10 \mathrm{~cm}$ 程度の高さで行われる台切り
をも可能とするために，刃の厚さを上邓 $4 \mathrm{~mm}$ ，下刃 4.5 $\mathrm{mm}$ とし，切断角 $25^{\circ}$ ，〈さび角 $30^{\circ}$ ，㺫刃のピッチ 45 $\mathrm{mm}$ で，各邓は一枚ずつ鋲でかしめ，刚幅 1,400 mm の 直線刃である。

\section{4 試験結果と考察}

場内在来種園の樹高䄪 $70 \mathrm{~cm}$ のものを延べ $150 \mathrm{~m}$ 程度， 地上高約 $30 \mathrm{~cm}$ の高さ，(深さ $40 \mathrm{~cm}$ ）でせん枝を行い， せん枝後 $450 \times 200 \mathrm{~mm}$ の恽を用いて切断された枝条の本 数と直径を測定した。なお，作業条件は前進速度 0.25 $\mathrm{m} / \mathrm{sec}$, X开の往復数約 800 c.p.m，切断ピッチ約 1.9 cmである。

湘定結果は表 1 のと㧍りで，薑続作業も可能であった。 また，刈跡の観察でも䒩株の両すそ部分が若干刚り残さ れる程度で汪整一と認められ，所期の目的は達成され たあのと判断される。しかし，台切り（太さ䄪 $2 \mathrm{~cm}$ 以 上）については，伝導軸の $5 \mathrm{~mm}^{\phi}$ ロールピンが切断さ れるなど抵抗がきわめて增大するため，強度の問題，あ るいは邓型等について 再検討を要するすのと思われる。

表 1 测 定 結 果 (1972)

\begin{tabular}{c|c|c|r|r}
\hline 回数 & $\begin{array}{c}\text { 項小直径 } \\
\mathrm{mm}\end{array}$ & $\begin{array}{c}\text { 最大直径 } \\
\mathrm{mm}\end{array}$ & $\begin{array}{c}\text { 平均直径 } \\
\mathrm{mm}\end{array}$ & $\begin{array}{c}\text { 数 量 } \\
\text { 本 }\end{array}$ \\
\hline 1 & 3.6 & 10.0 & 6.8 & 26 \\
2 & 3.0 & 13.0 & 8.0 & 34 \\
3 & 4.4 & 10.5 & 7.5 & 36 \\
4 & 4.4 & 10.6 & 7.5 & 31 \\
5 & 5.0 & 11.5 & 8.3 & 18 \\
6 & 4.7 & 18.0 & 11.4 & 32 \\
7 & 3.3 & 15.0 & 9.2 & 37 \\
8 & 3.2 & 10.6 & 6.9 & 21 \\
9 & 3.0 & 20.0 & 11.5 & 22 \\
10 & 4.2 & 9.0 & 6.6 & 38 \\
\hline
\end{tabular}

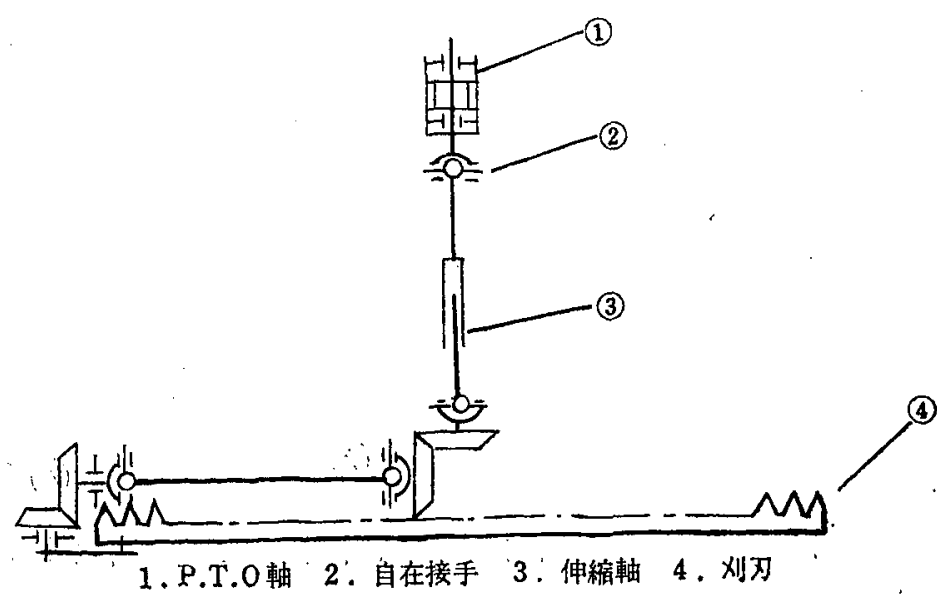

因2刈对動, 力伝達図 


\section{3 すそ刈り装置の試作}

乗用摘採機で摘探する場合に限らず，茶園管理作業の 機械化のためには，少なくとも車輸幅以上の5ね間が必 要で，しかも茶らねの両すて部は整一となっていること が望ましい。また，茶のらね閐は一度すそ刈りして広げ ても，比較的短期間に狭められ，世九枝よりるすそ刚り の頻度の恬5が激しいものと思われる。したがって，茶 園管理作業を機栈化するために必要な装膡の一つである と考充られる。

\section{1 試作装置}

過去 2 年間にわたる予備試験の結果から，油王操作に よるค板刃を上下運動させながら前進する機構の廃止， たわみ軸を用いて 月板刃を駆動させたるのを，強度的な 問題から伝導法の変更，あるいは合い対する円板刃に角 度を持たせるなどの改良を重ねた結果 図 3 のごときすを 刈り装置を試作した。

装置は図 3 にみられると括り，月板刃 $(700 \mathrm{~mm}$ 用数 12）4枚を用い，一度に二つのうね間のすそ刚りができ るものである。本体は摘採機後部の油圧 3 点ヒッチに直 装され，杊刃の駆動はP.T.O 粙から自在継手，伸縮軸,， 、ベルト等で行われる。なお，機体のだ行に伴う左右調 節は，捅探機と同様りンク機構により可能である。

\section{2 試駼結果と考察}

円板內の直径が大であるため，刚取り中に上下運動さ せる必要はなく，機体のだ行による若干の左右調節のみ でよいため，装置の大きな摇れが生じなく，蟥将满足す べき結果を得た。しかし，調節機構の関保から，樹冠部 を上回る任ど刈刃を上げることが不可能゙゙あるだめ，潘 場への出入りに際し, 枕地㑑当の広さを必要とするこ とが問題点として指摘された。

\section{4 サブソイラーの試作}

乗用摘探機の運行によって，5权間は乞の車輪の踏圧 により固められる。したがって，土壤条件を改善するた めの心土耕，耕盤の破䂶を目的としたサプソイラレ゙を設 計，試作した。

図 4 亿示すように，後述の中耕，施盵装置と一体化し た構造の直装式 25 和用である。お゙゙ル数恃 15 和 2 連 であるか，取り外しる可能となっている。

\section{1 試験結果と考察}

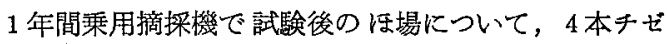
ルで実施した結果，平均 $18.8 \mathrm{~cm}$ の梁耕が行われた。 た，あらかじめ試験筒所を， SR-II 型土譬抵执測定器に より貫入抵抗を測定した結果は表 2 のと㧍りで，摘探機 の踏圧が地下 $25 \mathrm{~cm}$ 程度まで政ら゙ものと考光られるが，

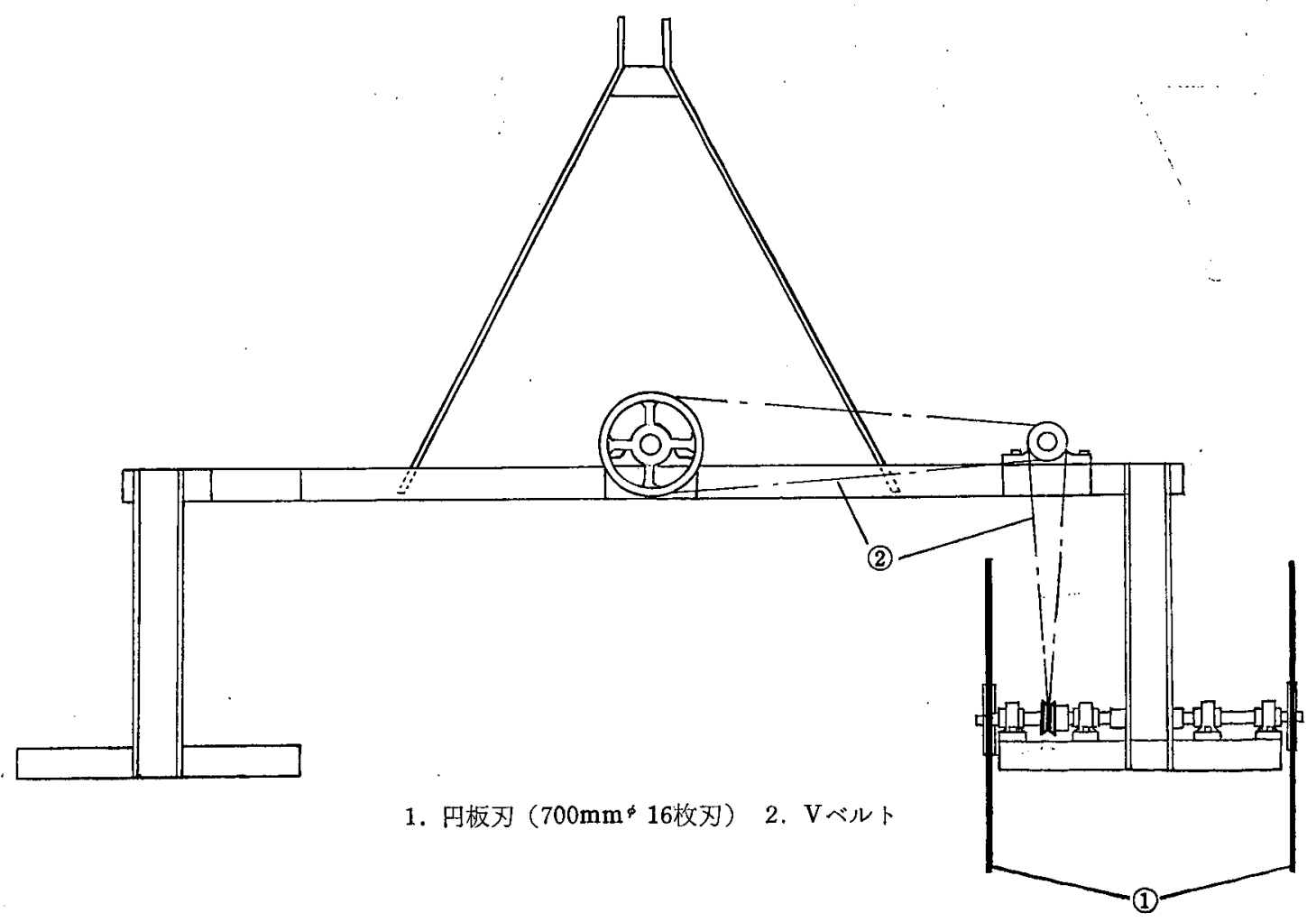

図3すを刈装置 


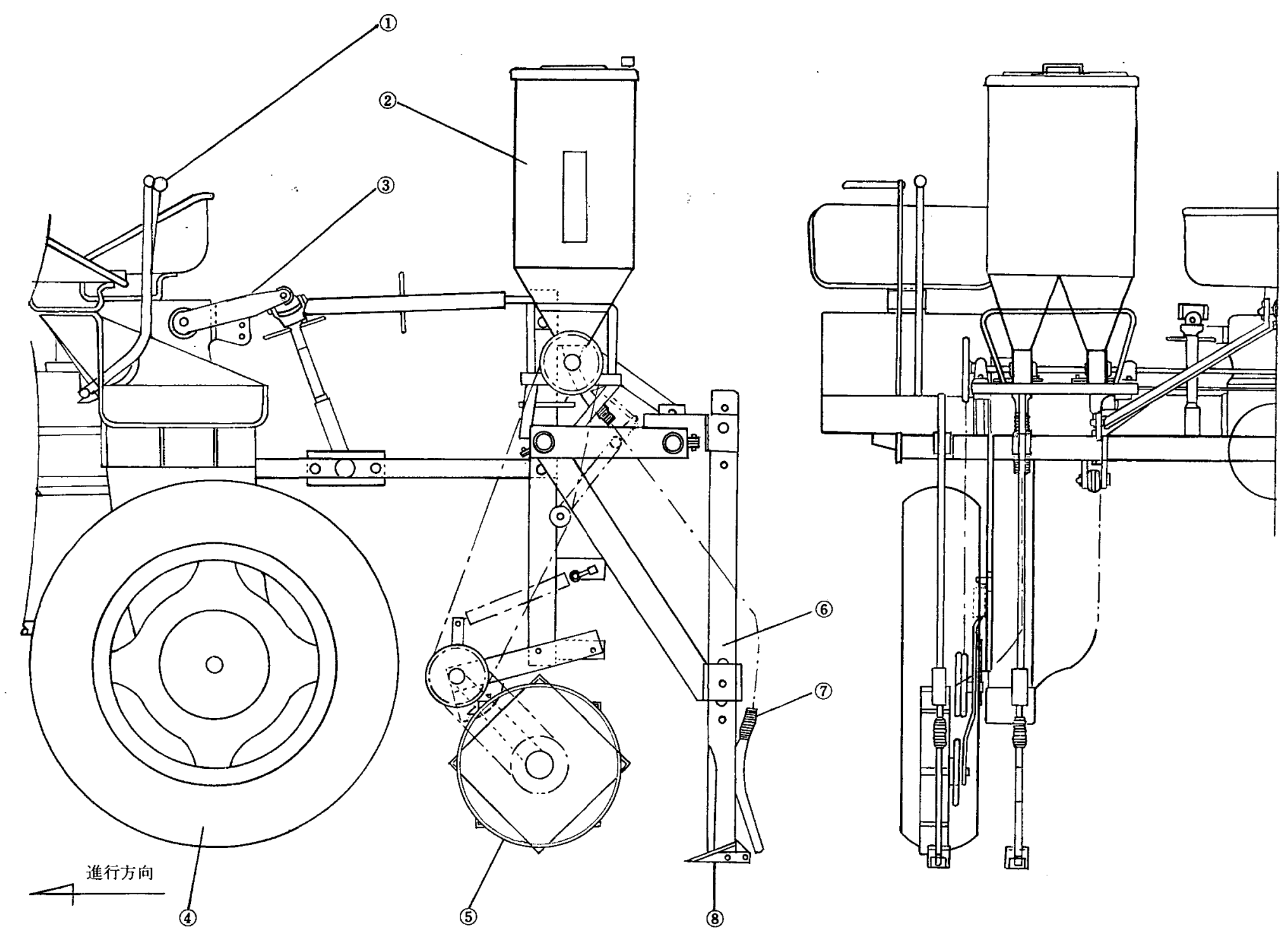

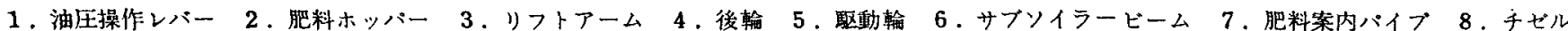




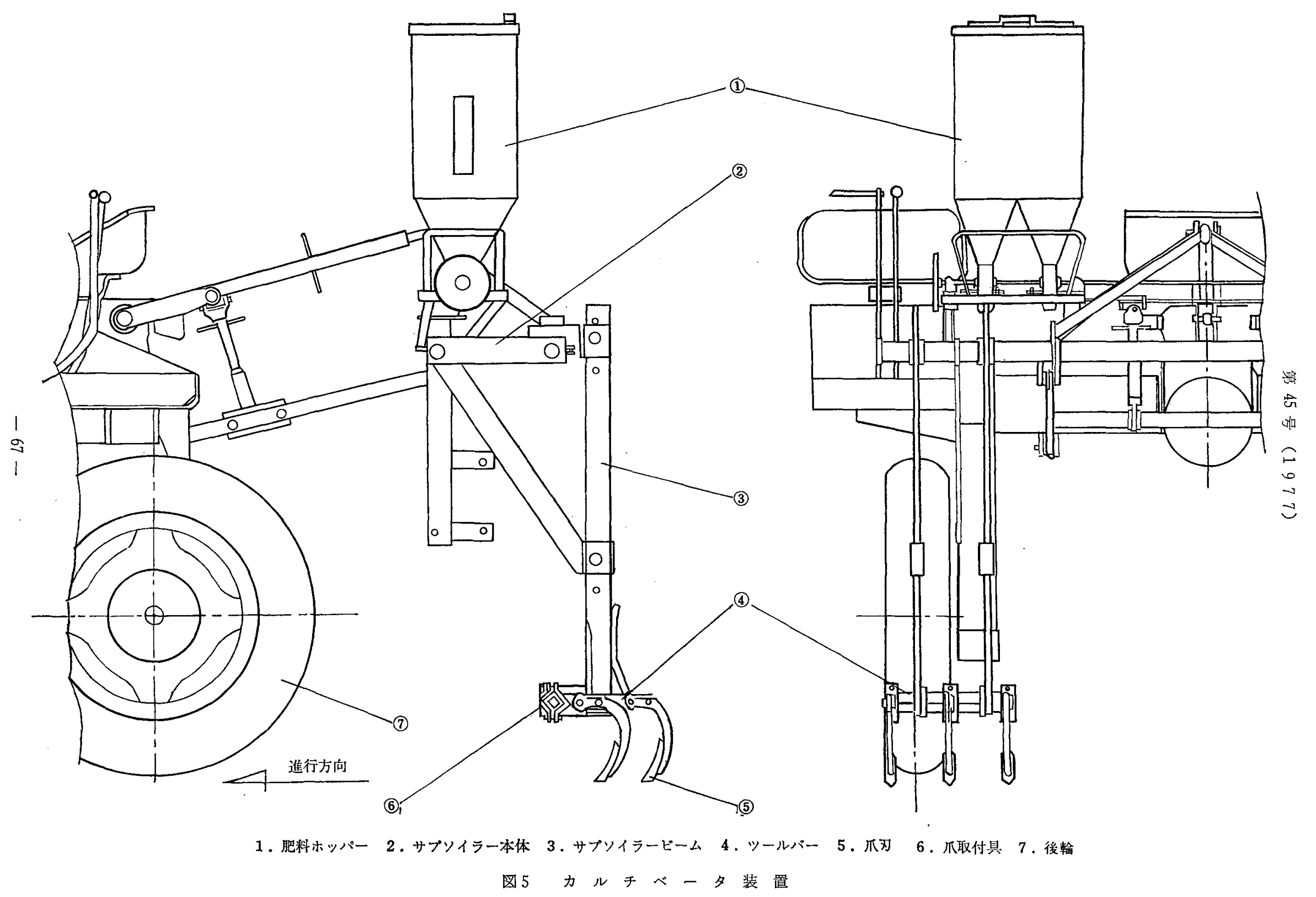


表 2 土墥調 查

\begin{tabular}{c|c}
\hline $\begin{array}{c}\text { 深 } \\
\mathbf{c m}\end{array}$ & $\begin{array}{c}\text { 円錐貫入抵抗 } \\
\mathbf{k g} / \mathbf{c m}^{2}\end{array}$ \\
\hline 5 & 19.2 \\
10 & 16.4 \\
15 & 13.4 \\
20 & 13.2 \\
25 & 12.7 \\
30 & 11.8 \\
35 & 11.5 \\
40 & 11.7 \\
\hline
\end{tabular}

特に梁さ $10 \mathrm{~cm}$ までは強く固められて括り，それ以上の 潹さでは影㗽が少ないので，約 $19 \mathrm{~cm}$ の深耕ができれば， 摘雨機に上る踏压の影響を除く目的には十分に対応でき るものと思われた。なお，一般的には 17 PS 程度のホイ ール型トラクターで，しかも4連でこれだけの耕うんが 得られることは常識外のように思われるが，摘探機の重 心が相当前方に位置しているため，スリッブが起こりに くいことによって得られた効果と侤えている。

\section{5 中耕除草装置の試作}

茶園 5 和閐の中耕除草蔆置として、ッールバー型カル キベーターを試作した。

図5にみられるよ5に，ッールバーをサブソイラーの チゼルを取り外した穴を利用して取り付け，これに 3 本 の目的に応じた耕爪または除草爪を装着した 25 ね用で ある。なおリジットタイン执よび爪刚は，乘用トラク ター用の市販品である。

本装置については，特に詳細な試験は実施せず，単に 観察によって効果を見たのみである。その結果，中耕に ついては問題ないよ5に見受けられるが，除草爪により 地表を浅くかき削って草根を切る作業は，摘探等の前作 業によって相当車輪跡が沈下して扣り，かつ踏圧により 固められているため，爪州の角度，高さ等の調整が非常 にむつかかしく，技術的には可能であってる実施は困難と 判断された。

\section{6 施肥装置の試作}

前述したように，サブソイラーと一体化した構造のリ ヤマウント型である（因 4 参照）。

肥料ホッパーは 2 個, 繰出部は羽根口ータ型式（幅30 mm） 4 カ所として，盵料昍出管をサブソイラービーム の後方に装着し，作条器はサブソイラーを兼用とした。 したがって，条施用であり，かつ深層施肥も可能である。 なお，サブソイラーのキゼルを取り外し，カルチベーター
による中耕を兼ね施肥することる可能であり，この場合 には肥料をカルキベーターの前方に落下させる。また絽 出部の駆動には駆動輪を用い,チェーンにより伝導した。

\section{1 試験結果および考察}

ほ場外々おいて繰出部開度と施肥量の関保を $5 \mathrm{~m}$ 長間 の落下量で測定し， $10 \mathrm{a}$ 当りに換算（10a の施肥距離を 茶園の 5 間の延長 $355 \mathrm{~m}$ として計算)すると図 $7-1$, $2 ， 3$ のごとくであり，作業能率を人力施肥 (10 a 当り 中耕を含めて 3 時間と仮定）と純作業㭙間で単純に比較 すると約 10〜30 倍となる。しかし，図7亿みると批， 夏期追肥用としては结湾十分な落下量と思われるが，基 肥としての秋肥，春肥用としては低速，最大開度に战い て $95 \mathrm{~kg}$ 前後の落下量ではやや不足するるのと思われた

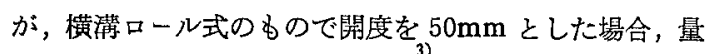
的に十分な成績を納めた試験結果が，庇児島県茶試で得 られているので，繰出部のロール幅の改善で解決できる と考光，棈造的にはこの䒾置が使用できることが謵めら れた。

\section{7 防除装置の試作}

茶国の病虫害防除には，主として噴篛機が用いられて いるが，乗用摘探機の集葉に使われている風力を利用す るためと，用水に之しい䒩園の妾地条件を考古，送風散 布式防除機，すなわち，ミス下機による防除装置を試作 した。なお，使用した噴頭は，粒子の性状が比較的整一 であるといわれている西独製のミスト機，マイクロンを 利用することとした。

装置は図 6 に示すように，噴頭 2 個をリフトフームに 值装し，レバーにより噴頭を左右に振らせ，一度に3う ね散布しようとするすのである。

\section{1 ノズルに関する調查}

ノズルの口径と噴雾粒子の関係は表 3 のごとくである。

表 3 粒子調查 (1966)

\begin{tabular}{|c|c|c|c|c|c|}
\hline No. & ノズル & $\begin{array}{l}\text { 全平均 } \\
\text { 粒 径 }\end{array}$ & $\begin{array}{l}30 \mu \text { 是 } \\
\text { 上平均 }\end{array}$ & 吐水量 & 備 考 \\
\hline 1 & $\begin{array}{l}\text { マイクロン } \\
00 \text { 番 }\end{array}$ & $26^{\mu}$ & $55^{\mu}$ & $\frac{\mathrm{m} l / \mathrm{min}}{440}$ & \\
\hline 2 & $1 \mathrm{~mm}$ & 31 & 61 & 380 & 試作ノズル \\
\hline 3 & 1.6 & 42 & 74 & 1,200 & $"$ \\
\hline 4 & 2.0 & 46 & 73 & 1,340 & $n$ \\
\hline 5 & 2.5 & 52 & 81 & 1,660 & $"$ \\
\hline
\end{tabular}

注 1 粒径測定には清水を使用した。

注 2 吐水量は液剂タンクを $0.5 \mathrm{~kg} / \mathrm{cm}^{2}$ に加圧して测 定した。

注 3 粓径は, スライドグラス上の受止油に採取したも のを投影機にて搪大して計測し，各ノズル200 個の 平均值である。

注 4 風量約 $40 \mathrm{~m}^{3} / \mathrm{min}$ に計測した値である。 


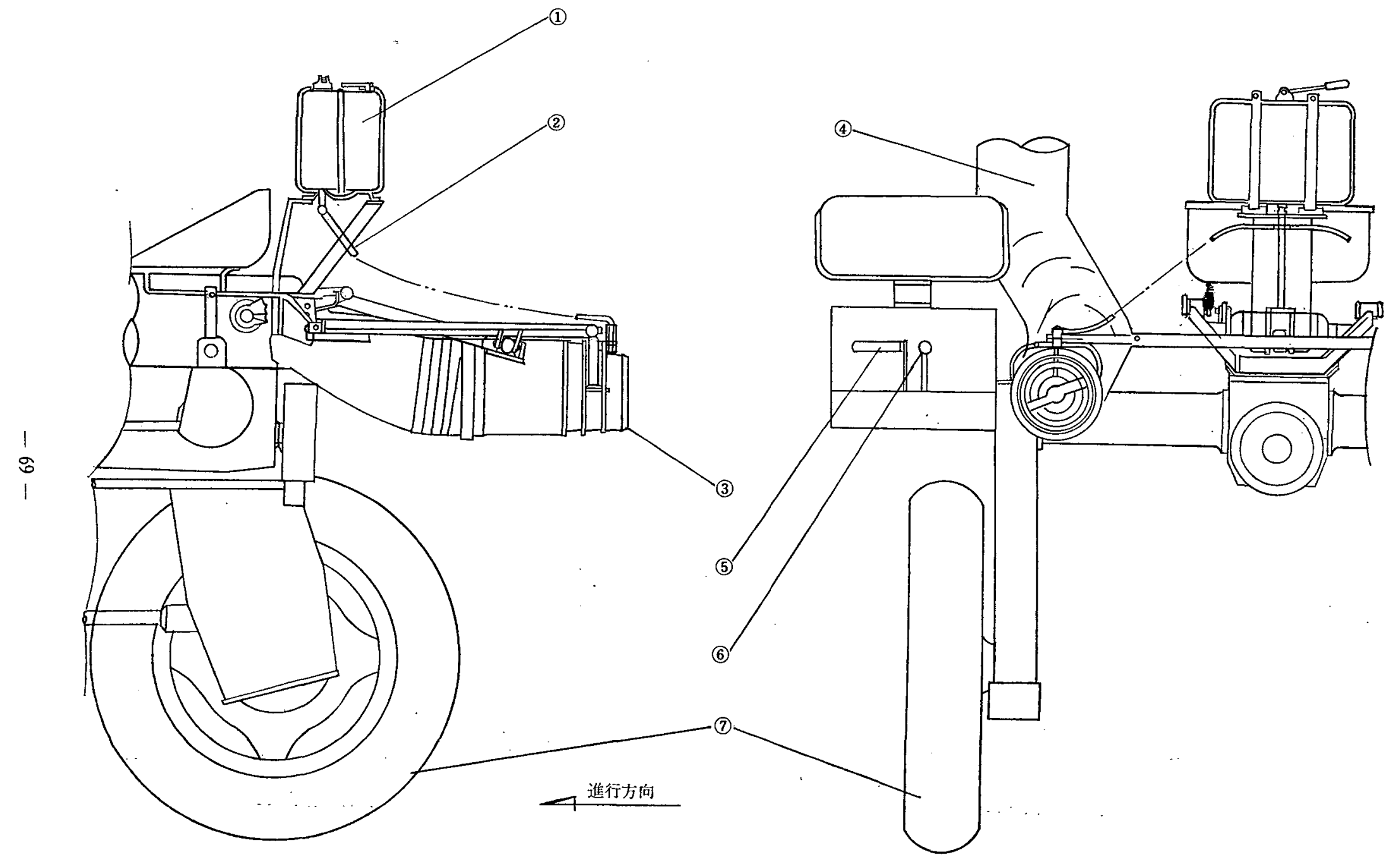

1. 薬液タンク 2 . 薬液ホース 3 . 噴頭 4 . 送風バイプ 5 . 摇動レバー 6 . 油圧操作レバー 7 . 後輪 因 6 氵 $、$ 㳖置 


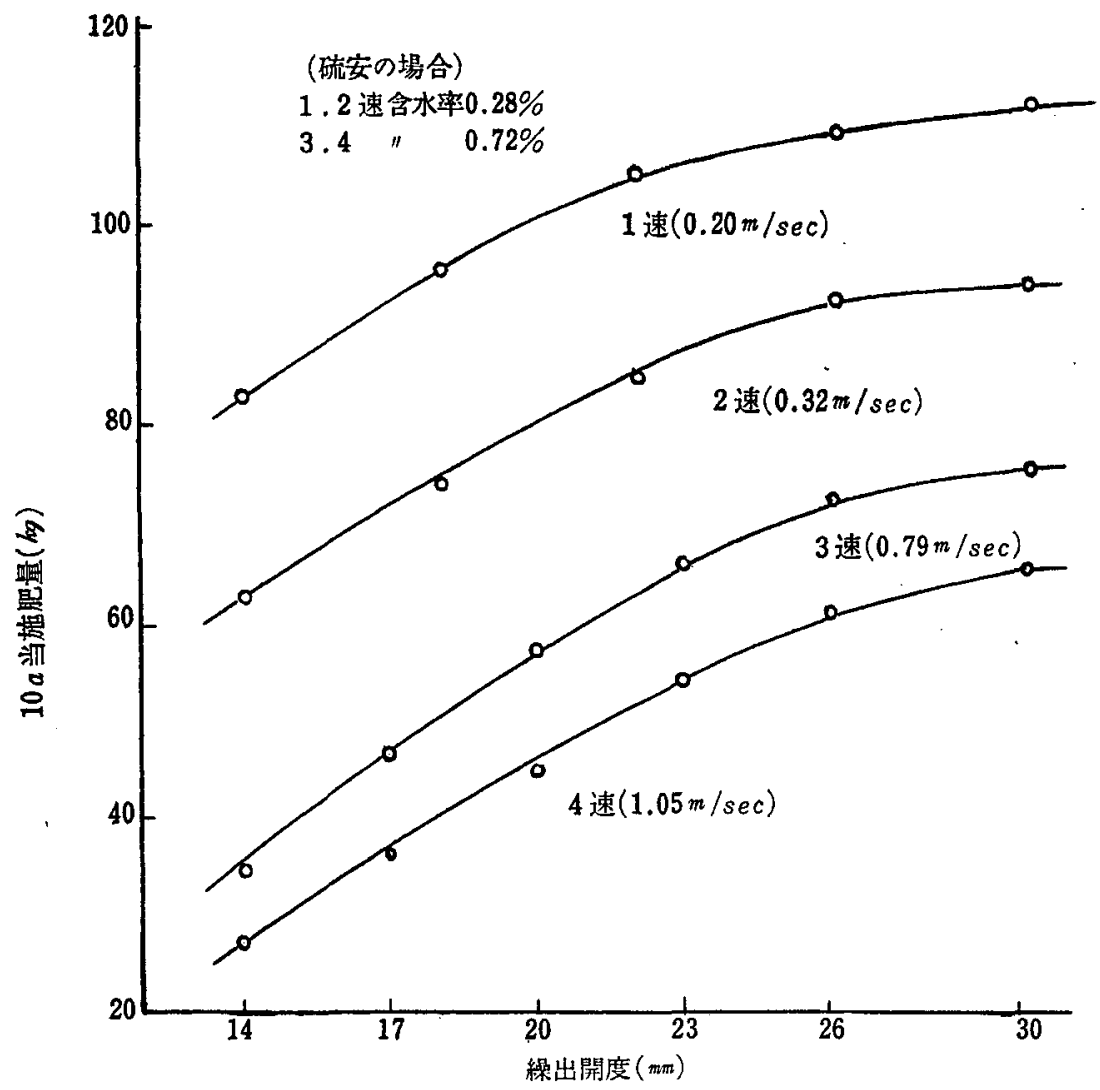

困 7-1繰出部開度之施肥量硫安の場弇

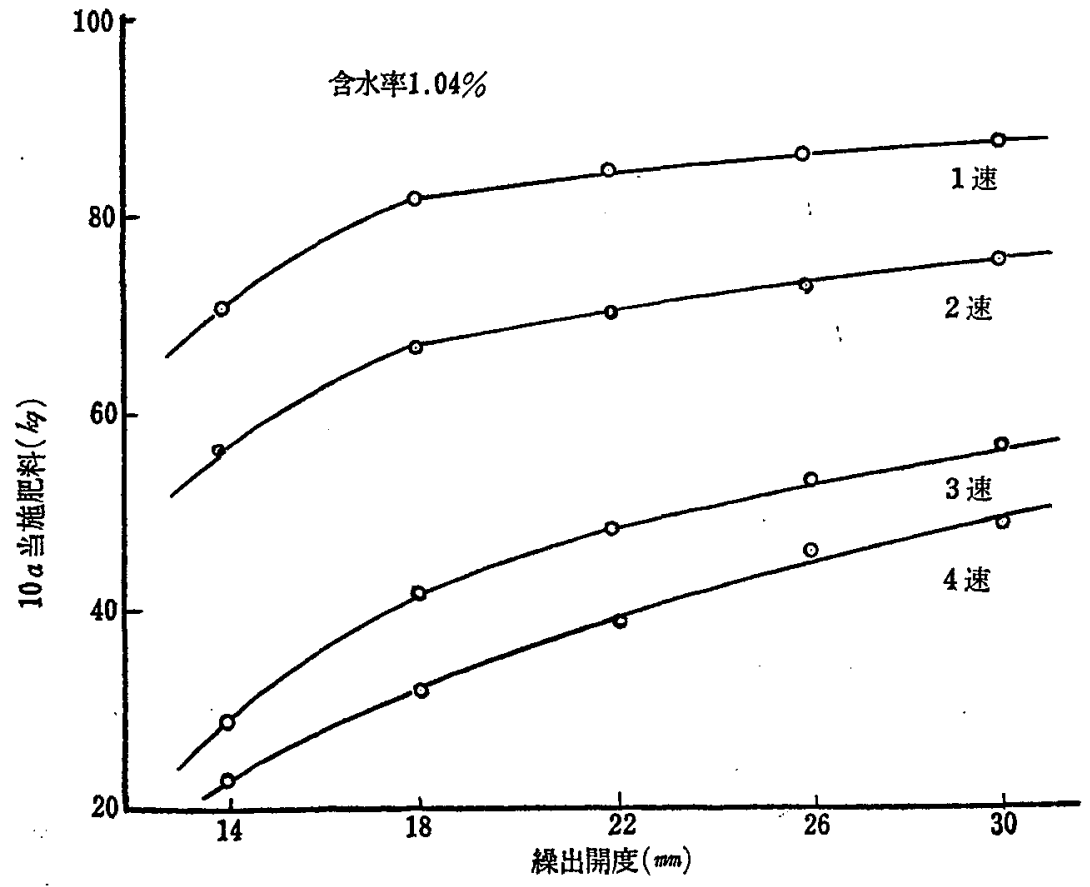

図7-2 尿素 の 場合 


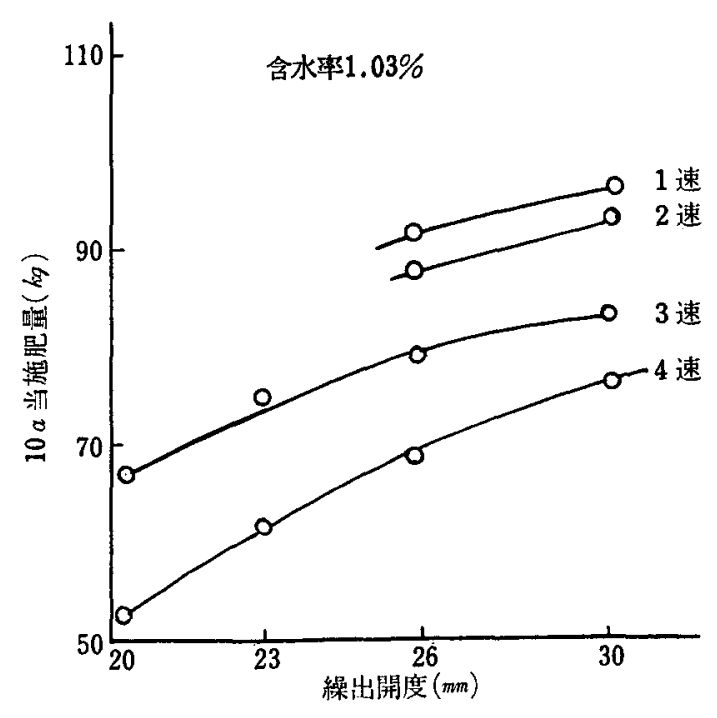

図 7-3 燐, 硝努, 加里の場合

表 4 アカダニ防除効果 5 月31日 使用農薬ケルセン

\begin{tabular}{|c|c|c|c|c|c|c|c|c|}
\hline \multirow{2}{*}{ No. } & \multirow{2}{*}{ 濃 } & \multirow{2}{*}{$\begin{array}{l}10 \text { a 当 } \\
\text { 散有 堛 }\end{array}$} & \multirow{2}{*}{ 敬布速度 } & \multicolumn{2}{|c|}{ 上部 防 除 率 } & \multicolumn{2}{|c|}{ 㑡 部 防 除率 } & \multirow{2}{*}{ 平均除 } \\
\hline & & & & 若葉 & 古葉 & 若集 & 古䐑 & \\
\hline 1 & $\begin{array}{l}\text { 倍 } \\
75\end{array}$ & $\frac{\ell}{17^{2}}$ & $\begin{array}{c}\mathrm{m} / \mathrm{sec} \\
1.1\end{array}$ & $81.9^{\circ}$ & $45.0^{\circ}$ & 83.9 & $54.3^{.6}$ & $66.2^{06}$ \\
\hline 2 & 75 & 17 & 1.1 & 87.5 & 56.5 & 84.3 & 58.4 & 71.7 \\
\hline 3 & 100 & 23 & 0.8 & 93.0 & 60.5 & 87.0 & 49.7 & 72.6 \\
\hline 4 & 100 & 56 & 0.3 & 75.0 & 51.2 & 90.9 & 74.5 & 72.9 \\
\hline $5 \lll$ & 100 & 23 & 0.8 & 90.2 & 40.9 & 79.3 & 41.8 & 63.1 \\
\hline
\end{tabular}

$※$ 貲頭左右摇動

一般的に 30 ミクロン以下の粒子だと風に乗って飛散あ るいは空中蒸発し易く， 50〜70ミクロン程度が良いとさ れているので，昍水量を可能な限り少なくし，平均粒径 を50ミクロン程度におさ光るようなノズルを試作してそ の性能を㒛べた。その結果は表 3 に示すと淤りで，前述 の理由からすれば，ノズル口径 $2.5 \mathrm{~mm}$ が良いものと 思われる。

\section{2 試験結果亡考察}

一番茶捎採後，ノズルロ径 $2.5 \mathrm{~mm}$ ，昍水量 $1.66 \mathrm{ll}$ $\min$, 平均䊉径 52 ミクロン（表 3 参照）のノズルを用 いアアカダニの防除を目的とした試験を実施した。その 結果は表 4 に示すごといで，これによれば，特に新芽に 対する防除率の高いことが䛺められ，薬剤の濃度差，散 布速度による差異はあまり認められなかった。このよう に，このミスト機による新芽のアカダ二防除には十分な 奻果が認められたので，奏用上は防除機として使用でき る確信が得られた。ただし，古葉に対する防除率がやや 悪いのは, 着葉角度の関係と考克られる。つまり, 古葉
は樹冠部を覆うような 着葉をしているので，葉の裏面に 液剂か十分に届かなかったためと考兄られ，これに対応 するには，今少し粓径を大きくして移動エネルギーを增 大することにより，防除率を向上させ得るむのと考克ら れる。

以上渠用摘採機のアタッチメントとしての茶園管理作 業装置の試作を実施したが，实用化するためには，もち ろん部分的な改善を要する点はあるむのの，前述の各装 置でむ，基本的には十分対応でき得るすのと判断され る。

なお，本研究を実施するにあたり，試作にご協力いた だいた石川岛芝浦機栈株式会社，内田为物工業株式会社， 初田工策株式会社，また，終始ご指樽を仰いだ吉谷製茶 部長，虫害研究室員，久能前機械研究室長ならびに機㭜 研究室員の各位に深く謝意を表する。

\section{8 摘 要}

1．せん枝装埴を設計，試作し，種々改良を重ねた結 
果，切断角 $25^{\circ}$ ，〈さび角 $30^{\circ}$ ，们刃のビッキ $50 \mathrm{mm，}$ 刈幅 1,400mm の直線往復動刃で, サイドドライブ方式 により所期の目的が達成された。

2. 直径 $700 \mathrm{~mm}$ の の板为（刃数 12）4枚により, 一度に 25 ね実施できるすそ刚り装置を開発した。

3. 車輪の踏圧による土壤条件を改善するため，15 ね2 連の 2 万ね用サブソイラーを試作したところ，約 $19 \mathrm{~cm}$ の深耕が可能で，踏圧の影響をほほ漂くことがで きた。

4.中耕, 除草用カルチベーターを試作した結果, 中 耕の目的は達成されたが，除草爪による浅耕は困難であ st。

5. $30 \mathrm{~mm}$ 幅の羽根ロータ型繰出装置による施肥装置 を試作したが，秋肥，春肥用としては施肥量がやや不足
々思われ，絽出部の改善の必要性が認められた。

. 6 . ミスト機による防除装置を試作し，フカダ二の防 “除試験を然施した結果，ノズル口径 $2.5 \mathrm{~mm}$ (平均粒径 52 ミクロン)では潼足すべき結果が得られた。

\section{9 文献}

1) 久能喜禄, 中野不二雄, 潼谷 洋, 鈴机勝弘: 茶業 試験場研究報告, No.11，25７2(1975).

2）佐藤清美：大型トラクター作業操典 (全購連), pp. 45 148 (1965).

3）鹿児島茶試：農林省総合助成訊験事業成績書， p. 29 (1970).

4) 今井正信 : 最新防除機（新農林社）， p. 58 (1966).

(Nov, 5, 1976) 